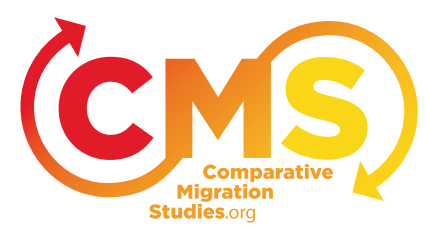

\title{
Immigrants and civil rights in cross-national perspective: Lessons from North America
}

\author{
Irene Bloemraad \& Doris Marie Provine
}

\author{
CMS 1 (1): 45-68 \\ DOI: $10.5117 / C M S 2013.1 . B L O E$
}

\begin{abstract}
The degree to which a nation envisions civil rights as applying to all residents offers insight into its commitment to and capacity for immigrant inclusion. A much-debated question is whether there is a trend toward convergence in national policies around immigrant inclusion, given globalization and the rise in human rights norms. Or do institutional legacies and domestic politics tend to preserve old approaches? This issue has been investigated most thoroughly in European contexts. Here we examine the cases of Canada and the United States. We find that while Canada and the United States, both settler societies, have much in common, they differ significantly in their historical experience with civil rights, which helps explain differences in how they approach the inclusion of immigrants in their societies. While civil rights has more potential for advancing immigrant concerns in the United States, neither country readily envisions immigrant inclusion as a civil rights issue.
\end{abstract}

Keywords: immigrant inclusion, civil-rights regimes, language of rights, convergence hypothesis, institutional legacies

\section{Introduction}

The growth in migration's scope and diversity has made immigration a newly salient policy issue in some nations, while reinvigorating longstanding debates about immigrants and immigration in others. Whether a new or renewed issue, political leaders face political, economic and social pressures to re-evaluate the rules regarding the entry and integration of immigrants, and also the rights migrants enjoy. Pressures for change are, however, counter-balanced by strong path-dependent processes embedded 
in existing law and institutions. Scholars consequently debate whether or not nation states are becoming more alike in how they address immigration. ${ }^{1}$ This question has been explored most intensively in Europe in comparative scholarship on immigration laws (Geddes 2003; Messina 2007), citizenship requirements (Brubaker 1992, Vink and de Groot 2010), integration policies (Goodman 2010) and immigrant rights (Soysal 1994; Koopmans, et al 2012).

Some argue for convergence. They identify a trend toward similar policies of entry, integration, and membership. Explanations stress the standardizing role of European institutions, such as the European Union, the European Court of Human Rights and FRONTEX (Geddes 2003), a growing, global human rights regime (Soysal 1994), or converging decisions by domestic courts that seek to adhere to common liberal principles of equality (Joppke 2001).

Others challenge the convergence hypothesis. These scholars argue that institutional legacies tend to lock in each nation's framework for dealing with immigrants (Goodman 2010). Koopmans and colleagues (2012) find more divergence than convergence across eight areas of immigrant rights in ten European countries from 1980 to 2008 . They argue that by $2002 \mathrm{a}$ trend toward inclusiveness had stagnated because of right-wing pushback. Domestic politics frequently reinforce pre-existing arrangements or, when change happens, domestic political pressures push it in diverse directions, not toward legally imposed convergence (Howard 2009; Koopmans, et al 2012).

Although these European nations are diverse in the relative importance of ethnic or civic national imaginaries, colonial histories, and culpability in acts of genocide during World War II, they share a collective history and highly articulated political umbrella. All of them feel the homogenizing influence of EU policy and judicial decisions, even if that influence is not nearly as strong as some of its original architects expected. The normative and agenda-setting role of the EU extends even to non-EU states such as Norway and Switzerland.

But what about patterns of convergence or divergence beyond Europe? Are global forces that favor possible convergence - such as the growing human rights regime and increasing economic integration - at work elsewhere? Or do domestic arrangements create "lock-in" effects that drive the development of law and policy on immigration in nation-specific ways? Asking these questions in a non-European context promises to broaden the insights from existing research and encourage further reflection on the European case. 
We take up this challenge by focusing on two neighboring immigrantreceiving states, Canada and the United States. We compare the two countries from the vantage point of civil rights policy. The political struggle in each nation over civil rights has been over who counts as a member, which, in effect, makes civil rights a measure of immigrant inclusion. A 'national models' perspective draws our attention to the political traditions and institutional arrangements that could create distinct trajectories in each country. Yet even those who take a strong national models approach in Europe acknowledge that in some areas, such as anti-discrimination law, we see a general trend toward expanded rights for immigrants and their descendants (Joppke 2007; Koopmans, et al. 2012), a convergence trend that might also affect North American nations.

The United States and Canada offer a particularly fruitful comparative framework in this regard (Bloemraad 2011). Both countries are settler societies characterized by a long history of immigration and similarities in language, economy, culture, and legal tradition. Yet we show that civil rights regimes - formal rules and systems, but also the taken-for-granted conceptualization of rights - are shaped by domestic legal systems, political institutions, and past responses to longstanding minority/ majority conflicts. Our analysis largely underscores the significance of historical institutions and ideological legacies in contemporary political struggles over immigrant civil rights, much like analyses of "locked-in" or path-dependent effects in European nations. We also find, however, some evidence of convergence traceable to both internal and external forces for liberalization.

Our analysis begins by defining "civil rights" broadly enough to permit comparative analysis. We turn then to the evolution of civil rights as an institutional and ideological project in each nation, demonstrating important differences between Canada and the United States in the role of courts as arbiters of conflict, in the relative importance of individual versus group rights, and in the extent to which the language of "rights" carries legitimacy in the public sphere. The final section suggests how these differences affect immigration policy and advocacy for immigrant rights in each country.

\section{What are "Civil Rights"?}

Articulating a definition of civil rights precise enough for analysis, but broad enough to apply cross-nationally forces us to theorize concepts carefully, one of the benefits of a comparative approach. In the United States, a written Constitution and Bill of Rights, combined with a 'separation of 
powers' system that gives substantial weight to judicial review, have made rights claims and court cases a central part of struggles for full citizenship throughout U.S. history. Canada, in contrast, did not have a document that corresponds to the U.S. Bill of Rights during most of its existence, rendering the formal court system less important to struggles over rights. The two nations also differ in where the impetus for rights claims has originated historically. In the United States, the struggle centered on race, while in Canada, it has been over English/French relations. These differences have affected the path each nation has taken to deal with minorities and civil rights, including differential emphasis on individual or group rights and different strategies to seek relief from discrimination.

Relations between local and national levels of government also differ, especially when it comes to immigration. In the United States, legislative action across levels of government is often adversarial, requiring judicial review. The Canadian approach rests more on inter-governmental negotiation and bureaucratic problem solving. Differing norms and strategies for resolving political conflict also affect the tactics of civil society actors. In the United States, both sides of the immigration debate frequently resort to litigation; in Canada, claims making is less centered on rights language and less likely to become a matter for judicial determination.

Such differences play out in the pages of newspapers and on television screens broadcasting the nightly news. In the United States, advocates concerned with immigrant incorporation tend to see the matter in terms of guaranteeing individual rights. Unions have organized cross-country "Immigrant Workers Freedom Rides" to draw links between the plight of contemporary immigrants and that of blacks in the segregated South of the 1950 and 1960 s.

In Canada, "civil rights" does not have the same resonance. Instead, immigrant advocates articulate notions of social inclusion and press government to aid immigrants in their efforts to enter the economic marketplace on fair terms. Organizations such as the Ontario Council of Agencies Serving Immigrants criticize the inadequacy of federal funding for immigrant integration and the weakness of legislative guarantees against discrimination, but the word "rights" is not prominent in their calls for action. In short, the two countries differ in the resonance of rights language in public debate, in the use of constitutional review, and in the role of courts generally in influencing civil rights and immigration policy.

To encompass both nations' experiences, we define "civil rights" to include the right of all individuals to expect equality before the courts, liberty of the person, freedom of speech and thought, the right to make 
contracts and own property, and freedom from discrimination by government or others in civil society. In the contemporary era, "civil rights" also involve attention to positive measures to ensure socio-economic equality through the labor market and schools, including affirmative action or equity hiring programs. In Canada, this approach sometimes encompasses "social rights" — state-provided benefits against the vagrancies of the market — and can be articulated as a call for social inclusion or social equity. In the United States, "civil rights" is not usually conceptualized broadly enough to include public benefits (Somers and Roberts 2008). ${ }^{2}$

\section{Civil Rights Traditions in the United States and Canada}

Canada and the United States share an English common-law tradition and commitments to the rule of law and personal freedom. They guarantee many of the same individual rights in their basic law, including liberty, due process, property, freedom of speech and equal opportunity. Antidiscrimination policy figures importantly in both countries. The Migrant Integration Policy Index (MIPEX) finds that the United States and Canada have the strongest anti-discrimination protections for immigrants out of the 31 democratic, highly industrialized nations surveyed (Migrant Integration Policy Index 2010). Many of these protections flow from civil-rights legislation and court cases. In the context of European debates over convergence or divergence, Canada and the U.S. share a similar legal and normative focus on liberal equality guarantees.

The path taken from colonial legal traditions to contemporary civil rights, however, has been very different, and we argue that this carries important repercussions for immigrants. In the United States, the idea of individual rights was enshrined in the Constitution from the country's earliest days as an independent nation and courts were charged with their enforcement against encroachments by every level of government. The Canadian equivalent to the U.S. Bill of Rights, the Charter of Rights and Freedoms is, in comparison, a new document, becoming part of the Canadian constitution in 1982. Before then, a system of parliamentary supremacy meant that legislation could not be challenged through individual rights claims. Advocates sought reform through challenges to the division of power between national and provincial governments and through efforts to change bureaucratic rules "from the inside." The 1982 adoption of the Charter started a "rights revolution" in Canada, bringing the legal strate- 
gies available closer to the U.S. system, but significant differences in the articulation and use of courts and rights language remain.

\subsection{The United States: Civil rights as a bloody political achievement}

Some U.S. civil-rights guarantees, arising out of English common-law tradition, preceded the War of Independence and helped establish the basis for the U.S. Bill of Rights. ${ }^{3}$ The imposition of limits on government power and a broad spectrum of guarantees against government intrusion into individual lives became key distinguishing marks of the new country. The institution of slavery, however, put the lie to the ideal of equal rights for all. Only after a civil war from 1861 to 1865 that killed 650,000 Americans did the $13^{\text {th }}, 14^{\text {th }}$ and $15^{\text {th }}$ amendments to the U.S. Constitution inscribe guarantees against discrimination on the basis of race and other factors. These amendments have defined battles over civil rights for racial minorities and immigrants ever since.

After the Reconstruction period following the civil war, many African Americans experienced second-class citizenship despite the constitutional language of equality. State and local law, especially in the South, segregated schools, public places and even drinking fountains. Yet although African Americans suffered egregious violations of constitutionally guaranteed civil rights, those rights, and the ideals they symbolized, provided a powerful basis for collective action. Wartime experiences with racial subordination, on the battlefields of World War II and on the home front, combined with continued segregation in schools and public facilities, gave impetus for a powerful, organized struggle for civil rights in the 1950s and 196os.

The civil rights movement blended a potent mix of moral suasion directed at legislators and the American public, street-level activism and police violations, as well as constitutional rights litigated in courts. Favorable court decisions helped the movement legitimate its demands and attract supporters (e.g., Kluger [1975] 2004). The movement eventually broadened to include claims of discrimination based on gender, disability, and sexual orientation and to encompass territorially incorporated minorities, such as Chicanos, Asians, and Native Americans.

Congress responded with landmark civil rights legislation. The Civil Rights Act of 1964 extended voting rights and outlawed racial segregation in schools, workplaces, and public accommodations. The 1965 Voting Rights Act requires federal oversight of the standards and procedures used by states to qualify voters and carry out elections. Both laws were strengthened through subsequent amendments, with the federal government acting 
under its power to regulate interstate commerce and to guarantee equal protection and voting rights under the $14^{\text {th }}$ and $15^{\text {th }}$ amendments. Congress and state legislatures have also developed other legal protections, bureaucratic institutions, and implementation policies, including affirmative action in contracting, employment and school admissions.

This civil rights saga highlights the significance of judicial review in American politics, which allows courts to overturn legislation, at any level, deemed in conflict with the federal constitution. Such court battles are frequent today around immigrant rights. The history of civil rights also reflects and reinforces the deep resonance that legal rights language has for Americans. Consider, for example, Martin Luther King, Jr.'s famous "I Have a Dream" speech delivered in 1963 on the steps of the Lincoln Monument. King condemned the continued existence of segregation and discrimination in legal terms, describing the Constitution as a "promissory note" to African American citizens that must be redeemed. This same language is resonant in contemporary immigrant rights advocacy.

\subsection{Canada: Civil rights through political compromise and the rights revolution}

In Canada, one seldom hears the term "civil rights" to refer to demands for equality and inclusion by minority groups. Instead, Canadians speak of equality guarantees, Charter protections, anti-discrimination initiatives and human rights. The difference in the language derives in part from the newness of written rights guarantees, which became part of the Canadian Constitution in 1982 under the Charter of Rights and Freedoms. The Charter established, for the first time, the fundamental nature of certain rights and freedoms, giving residents a means to challenge government in court.

Some protections in the Canadian Charter are of more limited scope than those in the U.S. Bill of Rights. In Canada, rights and freedoms are subject to "reasonable limits," a restriction open to interpretation by courts. Even if a court declares a law unconstitutional, federal and provincial legislatures have the power to override the decision. This power has seldom been exercised, but its inclusion leaves open the possibility that some rights can be circumscribed if government deems it in the public interest. At the same time, the Canadian Charter reflects consensus on the importance of equality of outcome (rights to) as compared to the greater American focus on freedom from. It also is attentive to group rights and group discrimination, enshrining the legality of affirmative-action programs. Thus, in some respects, the Canadian Charter is more protective of minority rights than the U.S. Constitution. 
Canada's enshrinement of group rights and its ambivalence about judicial review to over-ride political decision-making arise from its distinct political history. While the United States' struggle over civil rights grew out of what Gunnar Myrdal termed the "American dilemma" of subordinated black citizens and skin-color prejudice, the conflict in Canada arose out of what Hugh MacLennan labeled the "two solitudes," divided by language, culture and religion. These solitudes, a reference to divisions between French Catholics and English Protestants, date from the $17^{\text {th }}$ century.

Much of the English/French conflict has been worked out through uneasy political compromise rather than litigation. French Canadians used their demographic concentration in Quebec to acquire political power in the province. Those of French origin - increasingly self-identified as Québécois starting in the 1960s - have long understood their rights to be based on an assertion of collective peoplehood rather than individual interest. By the late 1970s, the native and Inuit peoples of Canada were making similar nation-based claims for autonomy and redress. Thus, in Canada, minority claims have been long couched in the language of group rights, rather than individual civil rights, and there is a tradition of trying to find political solutions, rather than judicial resolutions, to thorny problems. These traditions find expression in the Charter, and they affect how immigrants in Canada claim rights.

\section{Immigration Policy and Rights}

To understand the intersection of civil rights and immigration, we must understand how rights influence or stand apart from immigration policy. U.S. and Canadian immigration policies shared many similarities up to the $1960 s$. In the $19^{\text {th }}$ century, governments in both countries influenced immigration through regulation of transportation companies, homesteading requirements, and rules pertaining to major ports and railways, rather than through entry controls (Kelley and Trebilcock 2010; Zolberg 2006). Among the earliest attempts at entry control was legislation to prevent Chinese immigration. Race and nationality-based exclusions subsequently became widespread in law and bureaucratic practice, reflecting the belief among many politicians and ordinary citizens that the ideal immigrant should come from Europe, with preference for (Protestant) migrants from North and West Europe. ${ }^{4}$ Civil rights were not a consideration.

World War II laid a foundation for change. Military veterans, some of whom had married foreign nationals, pressed for immigration reform, while 
many people of all backgrounds rejected Nazism and the racial sciences associated with it. Human rights concepts and institutions took root and grew with the founding of the United Nations, the drafting and adoption of the International Declaration of Human Rights, and the flourishing of civil society groups and international non-governmental organizations. Following the war, the United States and Canada accepted "displaced persons" from Europe, the first step to formal refugee policies, and in 1952 the United States removed racial restrictions on naturalization. We thus find a modest influence of the burgeoning global human rights regime. Neither country, however, made radical changes to immigrant admission policies.

Distaste for racial or national-origin restrictions finally provoked policy change in both countries in the 1960s, but with strikingly different results. The United States chose family reunification as the major goal of admissions policy; Canadian governments promoted permanent immigration as a path to economic growth. Perhaps to facilitate its economic goals, Canada placed greater emphasis on fostering immigrant integration. Canada's approach has provided a base of public consensus that helps advocates push for expanded immigrant rights. The contrast with the United States is sharp. With few formal integration policies beyond a modest refugee resettlement program, the U.S. federal government has essentially left immigrant incorporation to families and ethnic communities, with some limited role for state and local governments. These policy choices have fanned public controversy over immigration.

\subsection{United States: Immigration policy as a product and producer of political controversy}

U.S. immigration policy has always involved political battles and behindthe-scenes bargaining among members of Congress. It is a process susceptible to interest group pressures and the public's anxieties about foreigners, bringing together, in Aristide Zolberg's (2006) words, "strange bedfellows:" social conservatives can pair up with unions and economic protectionists to oppose immigration, while social progressives join with big business to promote it. Immigration thus generates political landmines and internal divisions for both major U.S. political parties, rendering consensus difficult. Long periods of stasis are typical, with occasional bursts of transformative legislative activity (Tichenor 2002).

In the 1950s, pressure for immigration reform came from a diverse coalition of domestic actors and growing sensitivity to the ugly shadow of national-origin restrictions embedded in the Immigration Act of $1924 .{ }^{5}$ National-origin restrictions also contradicted the image America sought to 
project during the Cold War as a beacon of freedom and democracy. Every year from 1953 through 1965, legislators introduced bills to modify or dismantle the system. ${ }^{6}$ Finally, in 1965 , a buoyant economy, an overwhelmingly Democratic Congress, the work of presidents Kennedy and Johnson, and the death of staunchly restrictionist Congressman Francis Walter opened a space for reform.

As originally proposed by President John Kennedy in 1963 and introduced again by President Johnson in 1965, the new policy would have allotted fifty percent of all visas to labor migrants, with the remainder for family reunification. However, after the bill made its way through both houses of Congress, family reunification dominated what would be called the HartCeller Act. The Act instituted a system that allotted nearly three-quarters of all visas to family members, a practice that continues to the present.

The law also placed, for the first time, numerical limits on migrants from the "Western hemisphere," an area that includes Mexico, with no provision for the long history of Mexican migration and temporary labor in the United States. The result was large-scale unauthorized immigration as employers continued to solicit migrant labor while numerical limits restricted family sponsorship. To address this problem, the 1986 Immigration Reform and Control Act gave legal status to roughly three million migrants in exchange for sanctions on employers who hire unauthorized immigrants. Newly regularized residents could sponsor family to the United States, but quota limits created long waiting times and, consequently, renewed pressure to migrate without authorization. Employers continued to hire unauthorized immigrants, while the North American Free Trade Agreement arguably pushed more Mexicans northwards. By 2010, approximately 28 percent of all foreign-born residents living in the United States, over 11 million people, lacked legal residency status (Hoefer, Rytina, and Baker 2011).

This situation has generated significant political controversy. The 1986 law had been sold to the American public partly on the promise that it would prohibit employers from hiring unauthorized immigrants. Yet employers easily evaded the law and the federal government devoted few resources to enforcing it. Ironically, subsequent efforts to "harden" the southern border increased unauthorized migration as people who would have maintained homes in Mexico brought their families and settled permanently in the United States due to the difficulty of crossing (Cornelius 2005). Controversy also spread as unauthorized immigrants, once found mostly in the Southwest, settled across the country.

The laissez-faire approach to immigrant integration has also heightened controversy. Consider, for example, English-language instruction for im- 
migrants. In 2009, 91 percent of Americans felt it was very or somewhat important that immigrants speak English, but only 30 percent felt that the government should pay for English language classes (German Marshall Fund of the United States 2009). ${ }^{7}$ For other day-to-day practicalities-housing, education and the like-state and local governments are pretty much left on their own to manage and finance immigrant settlement.

In part because Congress has repeatedly failed to pass comprehensive immigration reform or provide much federal money for local costs, states and municipalities have reacted with their own legislation, much of it designed to deflect immigrants away from their communities. The result is a patchwork of laws, some of which attempt to restrict unauthorized immigrants from social services, higher education, and rental housing (Bloemraad and de Graauw 2012). Some states encourage local police to work with federal authorities to remove unauthorized immigrants or non-citizens who commit crimes (Provine et al. 2012). Such laws have provoked lawsuits and further politicized discussions around "rights" for immigrants.

\subsection{Canada: Greater consensus over an immigrant nation}

In 1947, Canada reaffirmed its commitment to a largely white and Britishcentric immigration policy. Prime Minster Mackenzie King famously stated that "the people of Canada do not wish...to make a fundamental alteration in the character of our population. ... any considerable Oriental immigration would give rise to social and economic problems" (Kelley and Trebilcock 1998: 312). By the 1960s, however, such racial prejudice was considered illegitimate, although the Canadian public, in the absence of a large non-white minority population, was less engaged with race issues than the United States (Reimers and Troper 1992). In 1962 and 1967, the government announced a set of regulatory changes to eliminate racial or national-origin exclusions.

The turnabout resulted in part from the efforts of churches, provincial human rights organizations, and ethnic lobbies, such as the Negro Citizenship Association. Within government, Canadian foreign service officers felt pressure from Commonwealth nations, notably in the Caribbean, to drop racial discrimination (Triadafilopoulos 2012). At the same time, government bureaucrats and key members of the Cabinet were highly attentive to economic considerations and fearful of an ever-expanding chain of family migration (Hawkins 1988 [1972]). From the government's perspective, immigration policy should primarily serve as an engine to drive forward Canada's economy and enhance population growth. 
The regulatory changes of 1967 , which were made into law and expanded in the 1976 Immigration Act, introduced a "points system" to select immigrants. Like the United States, Canada grants permanent residence based on family sponsorship, economic contribution, or refugee status. Canadian policy differs however, in placing much more emphasis on potential economic contribution when apportioning permanent resident visas. ${ }^{8}$ The government argued that such a system privileges merit-based migration, rather than focusing on skin color or origins. ${ }^{9}$

The Canadian parliamentary system and civil service tradition have helped defuse conflict and keep the details of policy negotiations out of the public eye. For much of the $20^{\text {th }}$ century, the Canadian cabinet minister in charge of immigration passed regulations and orders-in-council with limited intervention by Parliament. Even today, those seeking to influence immigration and integration policy must engage both politicians and a professional, technocratic public service that sometimes calls upon outside expert advice. ${ }^{10}$

Whether due to satisfaction with the broad contours of the policy, deference to elite consensus, or insulation from the nuts and bolts of policy development, the Canadian public largely accepts the number and composition of the immigrant stream. In the first decade of the $21^{\text {st }}$ century, Canada admitted 235,000 to 260,000 permanent immigrants each year, a higher proportion in relation to its total population than the United States. Of these immigrants, between 55 and 60 percent are economic migrants and their dependents, while 25 to 30 percent are family migrants, and 10-15 percent are refugees. More Canadians claim satisfaction with the country's immigration policy than residents of other Western nations, and there is no broad social movement or political party opposing mass migration. ${ }^{11}$ Indeed, the federal government is increasingly sharing responsibility with provincial governments in selecting economic migrants with provincial governments rather than fighting state or local governments in the courts, as in the United States. Public acceptance of the government's approach facilitates a more expansive articulation of immigrants' rights, including concerns about equality of outcomes.

\section{Immigration, inclusion, and rights}

Immigration policy in the U.S. and Canada has been shaped by domestic politics and prevailing beliefs about economic and foreign policy, with only occasional detours for humanitarian considerations. The rights of 
immigrants have been, at most, a minor concern. European scholarship suggests that the likeliest sources of change toward greater attention to immigrant rights come from domestic courts sensitive to a more inclusive vision of rights and international institutions pressing governments for more considerate treatment of immigrants. Some pressure toward convergence may indeed be coming from these sources, but comparison of each country's civil-rights history underscores the primacy of domestic political debate and action by internal advocates, including the growing immigrant population, in shaping policy. A key question is whether each nation's concept of civil rights is expansive enough to include non-citizens.

\subsection{United States: Civil rights for citizens only?}

In the United States, the language of civil rights, connected as it is to the ideal of equality, is potent and evocative. But civil rights, as Americans understand the concept, has built-in constraints. One limitation lies in the tendency to link civil rights with a particular legal status: citizenship. The protections of the Bill of Rights are actually more expansive, referring to "persons," not citizens or even legal residents. Even the $14^{\text {th }}$ Amendment, adopted in the wake of the Civil War, requires states to provide equal protection to all persons in their jurisdictions. But in the public sphere, equality and rights claims are often, implicitly or explicitly, linked to citizenship. Another important limitation derives from the narrowness of the nation's vision of full citizenship. In the United States, civil rights tend to be conceived as freedom from government interference, not rights to support from government as a prerequisite to civic inclusion.

What citizenship means in practice has been a source of deep division and struggle in the United States (Smith 1997), with the Civil War as perhaps the most famous example. Race or national origin has regularly trumped citizenship rights in times of national emergency. This was the case for Japanese American citizens interned during World War II out of fears over their potential collaboration with Japan, and for Muslim Americans placed under special surveillance in the wake of the September 11, 2001 terrorist attacks.

Nevertheless, American citizenship has, over time, gained a strong rights-bearing and protective character. The power of citizenship is evident when compared to the more limited rights of non-citizens. For example, in the 188 os, Congress first suspended, and then effectively ended, Chinese migration to the United States, at the same time banning Chinese already settled in the U.S. from citizenship. The Supreme Court upheld these laws in decisions that justified plenary power in Congress and the executive branch 
as a matter of national sovereignty. ${ }^{12}$ Congress has since used its power over conditions of entry and residence to define categories of membership, each with its own legislative and administrative bundle of rights and duties, including citizen, legal permanent resident, visitor, temporary resident, refugee, asylum seeker, or illegal migrant. Citizenship is the only status that brings the full protections of the Constitution to bear. For non-citizens, courts have given Congress the final authority to determine how much "personhood" an individual enjoys.

Fortunately for immigrants, U.S. citizenship is not hard to obtain, at least for legal residents. A legal permanent resident is eligible after five years and the requirements are not arduous. Once a person goes through the naturalization process, the law draws almost no distinction between native-born and foreign-born citizens. ${ }^{13}$ Birth in the United States, even to two non-citizen parents, also provides citizenship, ensuring full legal membership to the entire second generation, including the children of unauthorized residents. ${ }^{14}$

The Janus-faced inclusive/ exclusionary nature of U.S. law is critical to understanding how the United States can be an inclusive immigrant nation in some respects, while being capable of harsh, punitive action in others. An example is the tension between the plenary power doctrine that gives the federal government sweeping power over immigration, and the $14^{\text {th }}$ Amendment that protects "persons" against discrimination on the basis of race, national origin, and other characteristics. The Supreme Court has resolved this tension by forbidding state and local governments to discriminate on the basis of national origin. In a famous 1886 case, Yick Wo v. Hopkins, the U.S. Supreme Court overturned a San Francisco ordinance intended to shut down Chinese-operated laundries on $14^{\text {th }}$ Amendment grounds, upholding the right of Chinese non-citizen residents to be free of onerous regulation. ${ }^{15}$ Two years later the Court also famously used the $14^{\text {th }}$ Amendment to uphold the U.S. citizenship of US-born children, regardless of their Asian-born parents' ineligibility for naturalization. ${ }^{16}$

When the federal government takes action against immigrant residents, however, there are no similar constraints. In 1954, federal immigration personnel worked with state and local police agencies to "sweep" Mexican American neighborhoods and farms, and to stop "Mexican looking" people in a search for unauthorized residents. These operations, with little regard to rights of due process or protection from unreasonable searches and seizures or equal protection of law, led to the apprehension of 130,000 people in California, Arizona and Texas, and the displacement of upward of a million residents (Calavita 1992; Gracía 1980). Tellingly, "Operation 
Wetback" occurred the same year that civil rights for minority citizens took a significant step forward, first in the U.S. Supreme Court decision Brown $v$. Board of Education, which declared that school districts could not segregate students on the basis of race, and subsequently in Hernandez v. Texas, which held that the $14^{\text {th }}$ Amendment applies not just to African Americans, but also to other racially oppressed groups, including Mexican Americans.

Yet the civil rights paradigm does have traction in some cases affecting immigrants. The Civil Rights Act provided a legislative foundation to accommodate minority languages in public education, a policy that directly affected immigrants' children. In Plyler v. Doe, a close 1982 decision, the Supreme Court declared that children without legal status have a constitutional right to attend primary and secondary school. ${ }^{17}$ Concern over civil rights puts pressure on police departments to avoid racial profiling of residents, regardless of legal status, and unauthorized immigrants have full due process protections and the right to equal treatment when accused of crimes (Decker, et al. 2009). However, when non-citizens are caught up in immigrant detention or removal proceedings - which are outside the criminal justice system-many due process rights, such as access to a lawyer or the right to a bail hearing, are not available.

On balance, the tendency to conceptualize immigrant (foreigner) issues as distinct from civil rights (citizen) issues endures, influencing not just political and legal decisions, but also the attitudes and behaviors of other social actors, from police officers to social service workers. Within some spheres of civil society it is possible to discern a shift toward a more inclusive civil-rights perspective. For example, for years organized labor was hostile to workers without legal status, perceiving them as scabs undermining workers' ability to pressure employers. The civil rights activism of César Chávez and the United Farm Workers largely focused on legal immigrants and U.S. citizens. In 2000, however, the AFL-CIO took a historic volte-face, encouraging unions to organize unauthorized immigrant workers and supporting the legalization of settled immigrants without legal status as a matter of civil rights.

The tendency to frame civil rights as protections for citizens, not immigrants (whatever their status), remains entrenched nevertheless. Cuts to social benefits affecting resident immigrants - including legal immigrants were not generally perceived as a civil-rights issue when Congress passed the Personal Responsibility and Work Opportunity Reconciliation Act in 1996 (Yoo 2008). It is not particularly controversial that legal permanent residents get fewer social benefits than citizens, or that Congress has decreed that non-citizen immigrants, regardless of residency status, can be deported for 
relatively minor crimes. Unauthorized immigrants who may be members of American communities in an economic or social sense have limited legal protections. The absence of a robust conception of universal human rights in U.S. law, government, or politics means that rights, for these immigrants, are grist for the political mill.

\subsection{Canada: From few civil rights to human rights for all?}

Citizenship has been less of a historical rallying point in struggles by minorities in Canada to gain rights or in the willingness of courts to uphold them. This is partly due to how recently Canadians gained the familiar attributes of citizenship, such as an independent passport. It also lies in a legal tradition that puts less emphasis on citizenship, either as a protection or a source of benefits. A century ago, racial minorities were subject to the same discriminatory treatment regardless of whether they were immigrants or Canadian-born citizens. Ambivalence also arises from the nationhood claims of French-speaking and aboriginal minorities, who view appeals to Canadian citizenship as undermining their claims to self-determination.

As a legal category, Canadian citizenship came into existence on January 1, 1947. Before then, naturalized immigrants and those born in Canada were British subjects. This status provided few protections because Canada operated within the British tradition of parliamentary supremacy, which severely circumscribed the power of courts to declare government action unconstitutional. Asian-origin residents in the $19^{\text {th }}$ and early $20^{\text {th }}$ century, for example, had limited judicial recourse when the government of British Columbia denied them fishing licenses on racial grounds, or when the province refused to grant these residents, including those born in Canada, the right to vote (Roy 1989). ${ }^{18}$ It was not until after World War II that Canada lifted race-based voting restrictions. ${ }^{19}$

In Canada, the struggle for equal rights after World War II advanced, not through street demonstrations, but through advocacy by a coalition of civil liberties and human rights groups that used political, administrative and bureaucratic channels to push for anti-discrimination laws and human rights commissions. Canada had signed the Universal Declaration of Human Rights in 1948, and activists used its language to advance their claims. Beginning in 1962, provinces began adopting human rights legislation and in 1977, the federal government passed the Canadian Human Rights Act. These laws offered protections against discriminatory behavior by private employers and fellow citizens, but could not be used by individuals to challenge discrimination in Canadian law. ${ }^{20}$ The real rights revolution, in the opinion of many observers, occurred when Canada adopted the Charter 
of Rights and Freedoms, bringing greater judicial review and more legal channels to challenge inequalities (Cairns 1995; Ignatieff 2007). ${ }^{21}$ This has led to some convergence with the United States by increasing the salience of judicial review and discourses of rights-based claims making.

Perhaps surprisingly, given their prior reticence, Canadian courts have on the whole appeared more willing than their U.S. counterparts to apply Charter protections to everyone on Canadian territory, regardless of legal status. An early landmark upholding the rights of non-citizens was the Singh decision. ${ }^{22}$ Seven people who entered Canada and claimed refugee status had their claims denied by the Minister of Employment and Immigration and the Immigration Appeal Board. ${ }^{23}$ According to the Canadian government, claimants had no legal status in the country and could be returned to their homeland without further appeal. However, the Supreme Court invoked section 7 of the new Charter, which states that everyone has the right to life, liberty and security of the person. The Court determined that "everyone" includes every person physically present in Canada, regardless of legal status. Although subsequent court cases have specified when citizenship or legal status can be used for differential treatment, the Singh case enshrined the idea that constitutional guarantees apply to all, an interpretation that is on shakier ground in the United States.

Consensus over the benefits of immigration also provides a basis for a broader public discourse of inclusion. Because immigrants are seen as an economic and demographic asset, it is generally felt that government should help migrants integrate. Initially, government efforts targeted male breadwinners and set narrow goals for labor market participation, as when the 1970s Department of Manpower and Immigration encouraged immigrants to use government employment centers to find jobs and offered language training to those heading for the labor market. Starting in the 1980 , criticism by feminists and racial minorities widened the agenda, extending eligibility for language classes to both genders, regardless of work status, and directing attention to discrimination in the work force. The Employment Equity Act-first passed in 1986 and then amended in 1995-requires employers to take proactive steps to improve the employment opportunities of visible minorities, Aboriginals, women and people with disabilities. These laws are similar to those found in the United States, but the Canadian Charter of Rights and Freedoms explicitly shields such initiatives from "reverse discrimination" claims by majority residents, providing a stronger constitutional shield.

One might expect that the shared problem of discrimination would facilitate coalitions in Canada between immigrants and established 
minorities, but this has rarely been the case. In the United States such alliances sometimes flourish since the U.S. immigrant rights movement draws strength from the legal precedents, political strategies, popular rhetoric, and even former leaders of the African American and Chicano civil rights movements. In Canada, alliances between immigrants and longstanding minority groups - the Québécois, native peoples and Inuit—are largely non-existent because rights discourses are distinct. The claims made by Québécois and indigenous minorities are about self-determination, control over land, and collective rights as nations within Canada. These goals are seen as separate from, and at times in conflict with, a focus on individual rights and anti-discrimination guarantees. Thus, in 1971, when the federal government announced a new policy of multiculturalism that would celebrate the many cultural heritages of Canadians, some Quebec nationalists perceived a direct attack on their claims to group rights as a nation (e.g., Labelle, Rocher and Rocher 1995). Similarly, while immigrants and their descendants generally accept being labeled as one of many multicultural communities within Canada, Quebecers and natives reject this characterization.

These differences can cause political conflict. In Quebec, for example, there is controversy over Law 101, which, among its provisions, requires all immigrants who send their children to public schools to enroll them in French-language institutions, even if the family would prefer the Englishlanguage schools reserved for Quebec's longstanding Anglophone community. Quebecers defend this policy as essential to the vitality of the French language, and point out that immigrants in English Canada face de facto limited language choices in the public system. Opponents of Law 101 invoke individual rights to argue that immigrant parents should be able to choose freely among public schooling options. This clash led to one of the few times a government-in this case, the Quebec National Assembly-used the Charter's "notwithstanding" clause to overrule a Supreme Court decision that had declared parts of Law 101 unconstitutional. ${ }^{24}$ Canada thus differs from the United States in the degree to which common cause around civil rights serves as a bridge to other groups in society.

\section{Conclusion}

In the context of European debates over convergence or divergence around immigration, the US/ Canada comparison reveals some broad convergence, but also significant differences in the details of rights and policies directed 
to immigrants. Evolving human rights and anti-discrimination norms affected both countries in the 196os, but the "solutions" to the problem of national origin and race-based exclusions were divergent, with a focus, in entry policy, on family reunification and laissez-faire integration in the United States, and on economic growth and modest state-supported incorporation in Canada.

Similarly, in both countries, we see a slow, but noticeable, growth in the capacity of immigrant residents to make civil-rights claims and have them taken seriously, even for those without legal status. But again, the trajectories of prior rights battles shape strategies and outcomes. For example, the U.S. labor movement has drawn parallels between the conditions of undocumented migrants and the status of African Americans in the pre-civil-rights era, and also draws on past tactics that combine streetbased protest, legislative action and judicial strategies. In Canada, advocates for immigrants use protest and courts more rarely. The less-entrenched language and practice of individual rights blunt the strategy of court-based litigation, but facilitate political and bureaucratic appeals to social inclusion that move beyond civil rights to encompass social rights. At the same time, the history of minority/ majority conflict in Canada-centered on claims to nationhood by the Québécois and indigenous peoples-provides a shakier foundation for broad coalitions to combat discrimination than in the United States.

In making the case for national distinctiveness in North America, we underscore the extent to which past responses to longstanding minority/ majority conflicts affect the rights immigrants enjoy. The legacy of slavery and the civil rights movement in the United States, and the longstanding question of French Canadian membership in Canada, have powerfully shaped the way rights are understood in each country. These legacies shape claims and what rights are available to immigrants. Our findings thus suggest the value of analyzing conflict and negotiation over longstanding minority/ majority relations for their influence on the treatment of immigrants. Consider, for example, Koopmans and colleagues' (2012) finding that Belgium was an outlier in their analysis of European countries. This might be an outgrowth of the longstanding tension between French and Flemish-speaking Belgians.

Our findings also suggest that the role of courts and law in Europe may have been conceived too narrowly as a source of legal coercion that forces politicians and reluctant populations to be more liberal and expansive on immigrant rights than they might otherwise be. Our analysis shows how the language of "rights," particularly in the United States, resonates with 
broad social, political and even cultural content. Rights language carries normative legitimacy in the public sphere and frames the way people debate immigration. For those reluctant to extend rights to immigrants, especially unauthorized residents, a counter-narrative of citizenship restricts rights by legal status in the US. The US-Canada comparison also reveals tensions in rights appeals, notably around group versus individual rights. Our comparative analysis thus invites European scholars to think more capaciously about the language of rights and to be alert to alternative normative claims.

\section{Notes}

1. Cornelius, Philip and Hollifield (1994) were among the first to ask this question in a comparative framework. Its continued relevance is evident in the forthcoming third edition of their volume.

2. Various European nations provide robust social rights to migrants; some even allow noncitizens to vote in local elections, which neither the United States nor Canada does. This might suggest that Europe has embraced a stronger human-rights framework for immigrants than Canada or the United States. Yet cross-national policy comparisons indicate that many European countries lag behind their North American counterparts in ensuring basic civilrights protections, especially against discrimination (MIPEX 2010). While recent European Union policies, such as the EU Race Directive, are forcing member nations to make changes, the pace is slow and sometimes reluctant, with uncertain outcomes (Joppke 2007). Future research needs to examine these distinct constellations of rights.

3. The Bill of Rights, which refers to the first ten amendments to the U.S. Constitution, came into effect in 1791.

4. In both countries, Italian, Russian and Jewish immigrants were tolerated as only slightly better than non-Europeans, and as substantially inferior to West Europeans. For historic overviews of immigration policy, see Zolberg (2006) on the United States and Kelley and Trebilcock (2010) on Canada.

5. This law, also known as the Johnson-Reed Act, restricted migration from South and East Europe, and prohibited almost all Asian migration.

6. For more on this period, see Wolgin and Bloemraad (2010).

7. This compared to 48 percent of Canadian respondents who supported government funding.

8. Potential economic migrants accrue points for being of working age, having certain skills, and possessing advanced education. A much smaller group of business investors gain entry by making a significant financial investment in the Canadian economy.

9. While replacing race criteria with economic ones could be framed as a move to a merit-based system, critics note that if "merits" are defined as education and professional qualifications, then most people from developing countries will be shut out.

10. This is also the model for Canada's asylum policy, which is notable for its centralized administrative operations, in contrast to the more adversarial, legalistic American system or the fractured, politicized Australian one (Hamlin 2012).

11. Only 25 percent of Canadians surveyed in 2009 said that immigration is more of a problem than an opportunity, compared to 54 percent of Americans who viewed it as a problem 
(German Marshall Fund of the United States 2009). Opinion in Europe ranged from 43 percent of French who saw immigration as a problem to 66 percent in the United Kingdom.

12. Today, some commentators see less willingness by courts to uphold the plenary power doctrine that grants Congress ultimate authority over entry and deportation. Others, however, note that since 2001, the federal government has challenged non-citizens' rights to the most basic guarantees (such as habeas corpus) based on executive authority in matters of national security.

13. The one exception is the constitutional requirement that the President and Vice-President of the United States be "natural born" citizens. Canada makes no such distinctions; foreignborn individuals have served as prime minister of the country.

14. Like the United States, Canada gives birthright citizenship to all those born on Canadian soil. Canada and the United States are among few countries in the world with such inclusive jus soli provisions (Vink and de Groot 2010).

15. Yick Wov. Hopkins, 118 U.S. 356 (1886). Western states did pass laws barring those ineligible for naturalization from certain licenses and owning property. Since only Asians were ineligible for naturalization, these were effectively anti-Asian laws.

16. United States $v$. Wong Kim Ark (1898).

17. 457 U.S. 202 (1982). The court struck down a 1975 Texas statute that withheld state funds for educating children who had not been legally admitted to the United States and authorized local schools to deny them admission.

18. Although minorities in Canada had more limited judicial recourse when they suffered the prejudices of mass democracy, discrimination in the United States also occurred despite judicial review. Following the attack on Pearl Harbor, both countries required persons of Japanese ancestry-including citizens—-to leave their homes for internment camps or relocate far from the West Coast. War exigencies and fears have repeatedly led to civil rights violations in Canada and the United States, a pattern apparent in the contemporary responses to terrorism.

19. Chinese- and Indo-Canadians gained the right to vote in 1947. Japanese-Canadians were given suffrage in federal elections in 1948 and in British Columbia elections in 1949.

20. The Canadian Bill of Rights, enacted in 1960, sought to offer some protections, but it was a weak, declaratory document, with no inherent superiority over ordinary government legislation.

21. The Supreme Court of Canada heard only 34 cases concerning the provisions of the Bill of Rights, with a $15 \%$ success rate for claimants, over the Bill's existence (Knopff and Morton 1992). In contrast, within seven years of the Charter's enactment, the Supreme Court had heard one hundred Charter cases, of which $35 \%$ were successful (Morton, Russell and Withey 1992).

22. Singh v. Minister of Employment and Immigration, [1985] i S.C.R. 177 .

23. The U.S. government makes a distinction between refugees who make a claim for protection overseas and asylum seekers who make claims on U.S. territory. Canadian law does not make this distinction, thus in-land claimants are also called "refugee" claimants.

24. The case that spurred the use of the notwithstanding clause was Ford $v$. Quebec [1988] 2 S.C.R. 712 which focused on Law 101's language provisions for commercial signs. Political controversy over immigration, cultural accommodation and religious freedoms has also erupted over issues such as the use of religious law to resolve family disputes or women's right to wear head or face coverings in provinces such as Ontario and Quebec. 


\section{References}

Bloemraad, Irene. 2011. “"Two Peas in a Pod," “Apples and Oranges," and other Food Metaphors: Comparing Canada and the United States. American Behavioral Scientist 55(9): 1131-1159.

Bloemraad, Irene and Els de Graauw. 2012. "Immigrant Integration and Policy in the United States: A Loosely Stitched Patchwork." Pp. 205-231 in International Perspectives: Integration and Inclusion, edited by James Frideres and John Biles. Montreal: McGill-Queen's University Press.

Brubaker, William Rogers. 1992. Citizenship and Nationhood in France and Germany. Cambridge, MA: Harvard University Press.

Cairns, Alan C. 1995. Reconfigurations: Canadian Citizenship and Constitutional Change, Selected Essays. Toronto, ON: McClelland \& Stewart.

Calavita, Kitty. 1992. Inside the State: The Bracero Program, Immigration, and the I.N.S. NY: Routledge.

Cornelius, Wayne A. 2005. "Controlling 'unwanted' immigration: Lessons from the United States, 1993-2004." Journal of Ethnic and Migration Studies 31(4): 775-794.

Cornelius, Wayne A., Philip L. Martin and James F. Hollifield, (eds.) 1994. Controlling immigration: A global perspective. Stanford University Press.

Decker, Scott, Paul Lewis, Doris Marie Provine, and Monica Varsanyi. 2009. "On the Frontier of Local Law Enforcement: Local Police and Federal Immigration Law," in William McDonald (ed.) Immigration, Crime, and Justice. NY: Emerald: 261-277.

García, Juan Ramon. 1980. Operation Wetback: The Mass Deportation of Mexican Undocumented Workers in 1954. Westport CT: Greenwood.

Geddes, Andrew. 2003. The Politics of Migration and Immigration in Europe. London: Sage.

German Marshall Fund of the United States. 2009. Transatlantic Trends: Immigration, 2009. Washington, DC: German Marshall Fund. At http://trends.gmfus.org/immigration/doc/ TTI_2009_Key.pdf (accessed 16 February 2012).

Goodman, Sara Wallace. 2010. "Integration Requirements for Integration's Sake? Identifying, Categorizing and Comparing Civic Integration Policies," Journal of Ethnic and Migration Studies 36(5): 753-772.

Hamlin, Rebecca. 2012. "International Law and Administrative Insulation: A Comparison of Refugee Status Determination Regimes in the United States, Canada, and Australia." Law \& Social Inquiry 37(4): 933-968.

Hawkins, Freda. 1988 [1972]. Canada and Immigration: Public Policy and Public Concern. Kingston: McGill-Queen's University Press.

Hoefer, Michael, Nancy Rytina, and Bryan C. Baker. 2011. "Estimates of the Unauthorized Immigrant Population Residing in the United States: January 2010.” Office of Immigration Statistics, Department of Homeland Security.

Howard, M.M. 2009. The Politics of Citizenship in Europe. New York: Cambridge University Press. Ignatieff, Michael. 2007. The Rights Revolution. House of Anansi Press.

Joppke, Christian. 2001. "The Legal-Domestic Sources of Immigrant Rights." Comparative Political Studies 34 (4): 339-66.

Joppke, Christian. 2007. Transformation of Immigrant Integration: Civic Integration and Antidiscrimination in the Netherlands, France, and Germany. World Politics 59(2):243-273.

Kelley, Ninette, and M. J. Trebilcock. 2010. The Making of the Mosaic: A history of Canadian immigration policy, 2nd ed. Toronto: University of Toronto Press.

Kluger, Richard. 2005 [1974]. Simple Justice: The History of Brown v. Board of Education and Black America's Struggle for Equality. NY: Vintage Books.

Knopff, Rainer and F.L. Morton. 1992. Charter Politics. Toronto: Nelson Canada. 
Koopmans, R., Michalowski, I. and Waibel, S. 2012 "Citizenship Rights for Immigrants: National Political Processes and Cross-National Convergence in Western Europe, 1980-2008.” American Journal of Sociology 117(4): 1202-1245.

Labelle, Micheline, François Rocher and Guy Rocher. 1995. "Pluriethnicité, citoyenneté et intégration: de la souveraineté pour lever les obstacles et les ambiguïtés." Cahiers de recherche sociologique 25: 213-245.

Messina, Anthony A. 2007. The Logics and Politics of Post-WWII Migration to Western Europe. Cambridge University Press.

Migrant Integration Policy Index. 2010. "Anti-Discrimination Policy." Available at http://www. mipex.eu/anti-discrimination. Last accessed January 8, 2013.

Morton, F.L., Peter H. Russell and Michael Withey. 1992. "The Supreme Court's first one hundred Charter of Rights decisions: a statistical analysis." Osgoode Hall Law Journal 30(1): 1-56.

Provine, Doris M., Monica Varsanyi, Paul G. Lewis and Scott H. Decker. 2012. "Growing Tensions between Civic Membership and Enforcement in the Devolution of Immigration Control." In Punishing Immigrants: Policy, Politics, and Injustice,, Kubrin, Zatz and Martinez (eds.), NY: NYU Press.

Reimers, David M. and Harold Troper. 1992. "Canadian and American Immigration Policy since 1945." In Immigration, Language, and Ethnicity: Canada and the United States, edited by Barry R. Chiswick. Washington D.C.: The AEI Press.

Roy, Patricia E. 1989. A White Man's Province: British Columbia politicians and Chinese and Japanese immigrants, 1858-1914. Vancouver: University of British Columbia Press.

Smith, Roger M. 1997. Civic Ideals: Conflicting visions of citizenship in U.S. History. New Haven, CT: Yale University Press.

Somers, Margaret R., and Christopher N.J. Roberts. 2008. "Toward a new sociology of rights: a genealogy of "buried bodies" of citizenship and human rights." Annual Review of Law and Social Science 4: 385-425.

Soysal, Yasemin N. 1994. Limits of Citizenship: Migrants and Postnational Membership in Europe. Chicago: University of Chicago Press.

Tichenor, Daniel. 2002. Dividing Lines: The Politics of Immigration Control in America. Princeton: Princeton University Press.

Triadafilopoulos, Triadafilos. 2012. Becoming Multicultural: Immigration and the Politics of Citizenship in Canada and Germany. Vancouver: University of British Columbia Press.

Vink, Maarten P. and Gerard-Rene de Groot. 2010. "Citizenship Attribution in Western Europe: International Framework and Domestic Trends." Journal of Ethnic and Migration Studies 36(5): $713-34$.

Wolgin, Philip E. and Irene Bloemraad. 2010. "Our Gratitude to Our Soldiers": Military Spouses, Family Re-unification, and Postwar Immigration Reform. Journal of Interdisciplinary History 41(1): 27-60.

Yoo, Grace J. 2008. "Immigrants and Welfare: Policy Constructions of Deservingness. Journal of Immigrant and Refugee Studies 6(4): 490-507.

Zolberg, Aristide R. 2006. A Nation by Design: Immigration Policy in the Fashioning of America. Cambridge: Harvard University Press. 


\section{About the authors}

Irene Bloemraad, Sociology, University of California, Berkeley, Berkeley, CA 94720-1980. Corresponding author.

E-mail: bloemr@berkeley.edu.

Doris Marie Provine, Justice and Social Inquiry, School of Social Transformation, Arizona State University, Tempe, AZ 85827-6403.

E-mail: marie.provine@asu.edu.

\section{(c) (1) (8) $\Theta$}

This is an Open Access article distributed under the terms of the Creative Commons Attribution License (http:// creativecommons.org/licenses/by/2.0), which permits unrestricted use, distribution, and reproduction in any medium, provided the original work is properly cited. 